\title{
Participatory Evaluation and Selection of Improved Bread Wheat (Triticum Aestivum. L) Varieties in Northern Ethiopia
}

\author{
Berhanu Meles ${ }^{1}$, Chekole Nigus ${ }^{1}$, Atsede Teklu ${ }^{1} \&$ Yonas G Mariam ${ }^{1}$ \\ ${ }^{1}$ Tigrai Agricultural Research Institute, Axum Agricultural research Centre, Ethiopia \\ Correspondence: Berhanu Meles, Tigrai Agricultural Research Institute, Axum Agricultural research Centre, P.O. \\ Box 230, Axum, Ethiopia. E-mail: brehortic@gmail.com
}

Received: June 10, 2020 Accepted: July 17, 2020 Online Published: July 29, 2020

\begin{abstract}
Participatory variety selection trials were conducted in 2018 G.C in Laelay-maichew, Tahtay-maichew and Ahferom districts of central zone of Tigrai to evaluate the performance of improved bread wheat (Triticum aestivum. L) Variety and to assess farmers' criteria for bread wheat variety selection. Six improved bread wheat varieties (Mekelle-1, Mekelle-2, Ogolcho, Kingbird and Hedasse) including the most popular variety 'Kakaba' were used for the study at eighteen farmers (six from each district). The experiment was laid out using randomized complete block design at baby trial with three replications. Analysis of variance revealed a significant difference among the tested varieties for most of the agronomic traits except for kernels per spike and harvest index in all the tested locations. In the preference ranking, farmers used their own traits of interest which were very important in their wheat varieties for selection. Hence, common criteria's identified by the farmers to select the best varieties were; grain yield, biomass yield, earliness, disease resistance, spike length and seed size. Accordingly direct matrix ranking by farmers showed that Ogolcho was top ranked both at L/maichew and Ahferom followed by Kakaba, however Mekelle-1 was first ranked followed by Kakaba at T/maichew. Therefore farmers of L/maichew and Ahferom were recommended to use Ogolcho and Kakaba, whereas Mekelle-1 was recommended for T/maichew.
\end{abstract}

Keywords: participatory variety selection, direct matrix ranking, baby trial

\section{Introduction}

Wheat is a major cereal crop in Ethiopia, which is largely grown in the highlands and the country is considered the largest producer of the crop in the sub-saharan Africa (FAOSTAT, 2015). It is a cool-weather grain crop which is commonly grown at elevations ranging from 1500 to 3000 meter above sea level, with the most suitable regions fall between 1900 and 2700 meter above sea level (White et al., 2001). One of the major challenges for improving food security in rural resources poor farmers is to develop varieties that are breed for specific environments and preferred by the farmers

Varieties are typically developed at international or national center and incorporate a number of genetically useful traits, which are a major challenge for scientists with limited resources to test the full range of genetic diversity generated by a breeding program under all possible environments. Among the major challenges for improving the food security of resources poor communities is less availability of improved varieties for different agro-ecologies and preferred by the farmers Singh (2014). Researchers are the actors for the development of improved crop varieties and their production packages mainly in the research sites and farmers' field as verification trial in very few locations of the potential areas. Variety recommendation is also done based on the average performance of the varieties in most cases without considering genotype by environment interactions and farmers" needs and preferences, and the released varieties are distributed to the growers across the country (Workneh et al., 2014). This top-down approach did not convince the farmers to grow more improved varieties. Thus, in crop improvement and other technology development process the involvement of the end-users (participatory approach) may fasten the process and increase the adoption and dissemination of the new technology.

Participatory variety selection is a process by which the field testing of finished or nearly finished varieties, usually only a limited in number is done with the participation of the partners (Ceccarelli, 2012). It is a simple way for breeders and agronomists to learn which varieties perform well on-farm and preferred by farmers. Breeding and cultivar introduction programs produce and evaluate many varieties, and these varieties may produce high yield in researcher managed trials (on research station) but sometimes do not perform well in farmers' field or may lack a quality trait that is important to the farmers. Therefore, participatory variety selection is usually an integral part of 
participatory plant breeding, representing its final stage but can also stand alone if farmers' opinion is collected and used during the final stage (Ceccarelli, 2012). Participatory Variety Selections (PVS) can effectively be used to identify farmer's acceptable varieties that are better than old varieties with which farmers stick for long period (Witcombe et al., 1996). Farmers' participation in the PVS enabled them to increase their knowledge to select superior varieties that fit in their own agro economic and management condition. Farmers' low or lack of participation and failure to select best varieties is a costly mistake. That is; research costs can be reduced and adoption rates increased if farmers are allowed to participate in variety testing and selection (Joshi et al., 2002). A very important advantage of pvs is that the adoption of new cultivars is much faster than under the formal crop improvement and also the spread of varieties from farmer-to-farmer through the local seed system can be very fast (Bellon and Reeves, 2002). Participatory crop improvement may have many advantages, such as increased and stable crop productivity, faster release and adoption of varieties, better understanding of farmers' criteria for variety selection, increased cost of effectiveness and facilitated farmers learning (sperling 2001).

In Ethiopia, a number of improved bread wheat varieties have been released, however farmers cultivating old improved varieties which are either low yielder or susceptible to disease. Still, the ongoing efforts to improve access to and use of available technologies is below the requirements in terms of area coverage and number of beneficiaries in central zone of Tigrai. This is not because of potential agro-ecologies or high yielding bread wheat varieties, rather due to coordination and linkage in a sustainable way (multi-stakeholder approach). This zone is among the wheat producing areas of the region with different agro-ecologies, however farmers use only one improved bread wheat variety (kakaba) which is susceptible to the rust disease. Thus, having alternative improved varieties for the different agro-ecologies and for varying seasons is mandatory; having this information the following objectives were initiated.

\section{Objectives:}

To select high yielding and adaptive improved bread wheat variety/varieties using farmers' and breeders' selection criteria.

To increase farmers' awareness and their access to improved bread wheat varieties

\section{Material and Methods}

\subsection{Site DESCRIPTION}

The experiment was conducted at three target areas (woredas); Laelay-maichew, Tahtay-maichew and Ahferom. These areas represent the major wheat growing locations of central zone of Tigrai.

Table 1. Altitude, rainfall, temperature, latitude, longitude and soil type of study locations

\begin{tabular}{|c|c|c|c|c|c|c|c|c|}
\hline Location & $\begin{array}{l}\text { Altitude } \\
\text { (m.a.s.l) }\end{array}$ & $\begin{array}{l}\text { Total } \\
\text { rainfall(mm) }\end{array}$ & annual & $\begin{array}{l}\underline{\text { Temp }} \\
\underline{\min } \\
\underline{\max }\end{array}$ & ture $\left({ }^{0} \mathrm{C}\right.$ & Latitude & longitude & Soil type \\
\hline Hatsebo & 2118 & 782.8 & & 10 & 29 & $14^{0} 06^{\prime} 40.2^{\prime \prime}$ & $038^{0} 45^{\prime} 45.8^{\prime \prime}$ & Verti soil \\
\hline $\begin{array}{l}\text { Tahtay } \\
\text { maichew }\end{array}$ & 2090 & 656.6 & & 12.6 & 25.51 & $14^{0} 06^{\prime} 76.2^{\prime \prime}$ & $038^{0} 39^{\prime} 14.5^{\prime}$ & Clay loam \\
\hline Ahferom & 2214 & 690.5 & & 10.3 & 24.3 & $14^{\circ} 06^{\prime} 40.2^{\prime \prime} \mathrm{N}$ & $039^{0} 04^{\prime} 15.6^{\prime \prime} \mathrm{E}$ & Clay type \\
\hline
\end{tabular}

Source: National meteorological agency (Mekelle branch)

\subsection{Experimental Materials}

Six improved bread wheat varieties which were released from different research centers were used for the study. The varieties are listed in the table below and, 'Kakaba' was considered as a standard check which is widely cultivated by the farmers. 
Table 2. Description of experimental materials used in the participatory variety selection

\begin{tabular}{llllll}
\hline S.no & Varieties & Institution & Year of release & Altitude & Rainfall \\
\hline 1 & Kakaba & KARC/EIAR & 2010 & $1500-2200$ & $500-800$ \\
2 & Mekelle-1 & MARC/TARI & 2011 & $1980-2500$ & $300-500$ \\
3 & Mekelle-2 & MARC/TARI & 2011 & $1980-2500$ & $300-500$ \\
4 & Kingbird & EIAR & 2014 & $1500-2200$ & $500-800$ \\
5 & Hedasse & KARC/EIAR & 2012 & $2100-2800$ & $>600$ \\
6 & Ogolcho & KARC/EIAR & 2012 & $1500-2100$ & $500-800$
\end{tabular}

KARC $=$ Kulumsa Agricultural Research Center, MARC $=$ Mekelle Agricultural Research Center, EIAR $=$ Ethiopian Institute of Agricultural Research, TARI= Tigray Agricultural Research Institute

\subsection{Experimental Design and Field Management}

The varieties were planted in the first week of July 2018 production season and the experiment was conducted using mother-baby method. The mother trial was conducted on station using Randomized Complete Block Design (RCBD) with three replications and plot size of $2.5 \mathrm{~m}$ length by $1.2 \mathrm{~m}$ width whereas the baby trials were conducted at six selected farmers from each testing areas (a total of eighteen farmers) under their own cultural practices. Each farmer's field was considered as replication and, the varieties were randomized in each replicated field with plot size of $5 \mathrm{~m} * 5 \mathrm{~m}\left(25 \mathrm{~m}^{2}\right)$, thus the mother trial was used to generate breeders' data while the baby trial was used for participatory variety selection. The seed rate was $150 \mathrm{~kg} / \mathrm{ha}$ with spacing of $20 \mathrm{~cm}$ between rows, while the fertilizer rate was, Urea; $100 \mathrm{~kg} / \mathrm{ha} \mathrm{(1/3} \mathrm{during} \mathrm{planting} \mathrm{and} 2 / 3$ at tillering stage of the crop), blended fertilizer of $100 \mathrm{~kg} / \mathrm{ha}$ all applied at planting. The varieties were treated with full recommended wheat production packages (agronomic recommendations and practices).

\subsection{Data Collected}

Researchers collected important data from Mother Trials on economically important traits. These traits include: days to heading $(50 \%)$, days to maturity $(90 \%)$, plant height at physiological maturity, Spike length, kernels per spike, biomass yield, grain yield and harvest index. Data were collected from the four central rows and, five plants were randomly selected from the four rows to recorded data on traits like; plant height, spike length and number of kernels per spike.

For the farmers' data collection; the researches together with the district agricultural workers identified and selected farmers and fields for the trial. More than forty-five farmers of both sexes were participated and each location has about twenty-one evaluators of both male and female. Training on capacity building for farmers and development agents on bread wheat production and management packages (from site selection to post harvest handling) was given. Two randomly assigned replications were selected for evaluation at each location, and farmers evaluate the varieties at heading and physiological maturity stage. The overall performance of the varieties was evaluated at maturity stage by allowing farmers to select and rate each variety. The common criteria's identified by the farmers to select the best varieties were; grain yield, biomass yield, earliness, disease resistance, spike length and seed size. Direct matrix ranking method was used to rank the varieties with respect to each selection criteria as: $(5=$ excellent, $4=$ very good, $3=\operatorname{good}, 2=$ poor, $1=$ very poor $)$ based on consensus where differences were solved by discussion (Boef and Thijssen, 2006). A matrix was prepared as per the selection criteria: wheat varieties were listed in the row and traits in the column. The performance of the bread wheat varieties were evaluated and computed each other at each location. Seifu et al., (2018), Kifle et al., (2018) and Astawus (2016) has been used the same approach

\subsection{Data Analysis}

The data were subjected to R-software to analyze the breeders' data (data of mother trial) and, Statistical Package for Social Science (SPSS) Version 16 was used to analyze the participatory varietal selection data collected through farmer participation (preference ranking) 


\section{Result and Discussion}

\subsection{Researchers' Evaluation}

Analysis of variance showed highly significant differences $(\mathrm{p} \leq 0.01)$ for heading days and maturity days (Table 3,4 and 5) at both locations. The mean values for heading days ranged from 51.7 to 65 with mean of 57.1, 53.3 to 68.7 with mean of 58.83 and 54 to 70.33 with mean of 60.1 at laelay-maichew, Tahtay-maichew and Ahferom respectively. The number of days to physiological maturity (90\%) ranged from 97.7 to 111 at laelay-maichew, 93 to 107 at Tahtay-maichew and 83 to 111 at Ahferom. There was a difference in heading and maturity days between the locations which could be due to the difference in altitude, temperature and rain fall; therefore the highest days to physiological maturity variety (Ogolcho) is suitable for areas having optimum rain fall; laelay-maichew and Ahferom (adi-ahferom). Such a difference in days to heading and maturity among improved bread wheat varieties was also reported by Astawus (2016) and Ayalew (2017).

The analysis of variance (ANOVA) revealed that plant height, spike length, biomass yield and grain yield on mother trial were highly significantly different $(\mathrm{p} \leq 0.01)$ at the three locations, however there was no significant difference among the improved bread wheat varieties for the traits; kernels per spike and harvest index. Similar to the findings of the present study Kifle et al., (2018) have reported significant differences for plant height, spike length, biomass yield and grain yield. At all locations (laelay-maichew, Tahtay-maichew and Ahferom) the highest plant height; 82.7, 87.3 and $95.3 \mathrm{~cm}$ respectively was recorded from Ogolcho, while short plant height was recorded from Hedasse $(66.5 \mathrm{~cm})$ at laelay-maichew, Mekelle-2 $(82.9 \mathrm{~cm})$ at Tahtay-maichew and Mekelle-1 $(85.9$ $\mathrm{cm}$ ) at Ahforom. Spike length ranged from 6.1 to $8.1 \mathrm{~cm}$ at Laelay-maichew, 4.6 to $8.5 \mathrm{~cm}$ at Tahtay-maichew, and 7.2 to $8.8 \mathrm{~cm}$ at Ahforom. Similar to plant height, the highest spike length at all locations was recorded from 'Ogolcho' variety, thus the variety showed consistency which indicated less affected by the growing environments. In the present investigations kernels per spike was found to be non-significant. Though the varieties were not statistically significant, Ogolcho had the highest kernels per spike (38 and 46.2) at L/maichew and T/maichew respectively.

Analysis of variance revealed a significant difference among the tested improved bread wheat varieties for both biomass and grain yield at all the tested locations. Biomass yield ranged from 5333.3 (Kingbird) to 8666.7 (Mekelle-1) kg/ha, from 11000 (Mekelle-2 and Kingbird) to 14750 (Ogolcho) kg/ha and from 9000 (Kingbird) to 11666 (Ogolcho) $\mathrm{kg} / \mathrm{ha}$ at Laelay-maichew, Tahtay-maichew and Ahferom respectively. The highest grain yield was recorded from variety Ogolcho $(3386.7 \mathrm{~kg} / \mathrm{ha})$ followed by Mekelle-1 $(3319.3 \mathrm{~kg} / \mathrm{ha})$ at Laelay-maichew, variety Ogolcho (4715.7 kg/ha) followed by Kingbird (4561 kg/ha) at Tahtay-maichew, and variety Ogolcho (3750 $\mathrm{kg} / \mathrm{ha})$ followed by Mekelle-2 (3600 kg/ha) at Ahferom. The results indicated that Ogolcho and Mekelle-1were high yielder in both testing locations and perhaps would be widely adapted. This study is in agreement with study of Fano and Tadeos (2017) reported significant differences of bread wheat varieties for grain yield, however they reported non-significant difference for biomass yield which contradicted with the present study.

Table 3. Mean grain yield and agronomic traits of bread wheat varieties for at Laelay-maichew in mother trial

\begin{tabular}{lllllllll} 
& \multicolumn{2}{l}{ Varameters } & \multicolumn{7}{l}{ Karieties } & DH & DM & PH & SL & KPS & BY & GY & HI \\
\cline { 2 - 8 } Kakaba & $59^{\mathrm{b}}$ & $103^{\mathrm{b}}$ & $71^{\mathrm{b}}$ & $6.9^{\mathrm{bc}}$ & 33.5 & $7333.3^{\mathrm{b}}$ & $2772.2^{\mathrm{c}}$ & 0.38 \\
Mekelle-1 & $52.7^{\mathrm{cd}}$ & $100^{\mathrm{bc}}$ & $70.9^{\mathrm{b}}$ & $6.9^{\mathrm{bc}}$ & 35.1 & $8666.7^{\mathrm{a}}$ & $3319.3^{\mathrm{ab}}$ & 0.39 \\
Mekelle-2 & $55^{\mathrm{c}}$ & $101^{\mathrm{b}}$ & $70.7^{\mathrm{b}}$ & $7.3^{\mathrm{ab}}$ & 33.9 & $7333.3^{\mathrm{b}}$ & $2846.7^{\mathrm{bc}}$ & 0.39 \\
Kingbird & $59.3^{\mathrm{b}}$ & $101^{\mathrm{b}}$ & $69.8^{\mathrm{b}}$ & $6.7^{\mathrm{bc}}$ & 33.4 & $5333.3^{\mathrm{c}}$ & $2062.8^{\mathrm{d}}$ & 0.39 \\
Hedasse & $51.7^{\mathrm{d}}$ & $97.7^{\mathrm{c}}$ & $66.5^{\mathrm{b}}$ & $6.1^{\mathrm{c}}$ & 29.3 & $8000^{\mathrm{ab}}$ & $2879.2^{\mathrm{bc}}$ & 0.37 \\
Ogolcho & $65^{\mathrm{a}}$ & $111^{\mathrm{a}}$ & $82.7^{\mathrm{a}}$ & $8.1^{\mathrm{a}}$ & 38 & $8166^{\mathrm{ab}}$ & $3386.7^{\mathrm{a}}$ & 0.42 \\
\hline Mean & 57.1 & 102.3 & 71.93 & & 33.9 & 7472 & 2878 & 0.39 \\
Cv (\%) & 2.25 & 1.7 & 5.1 & 7.97 & 16 & 9.7 & 9.7 & 12 \\
Lsd (5\%) & 2.34 & 3.16 & 6.67 & 1.01 & $\mathrm{Ns}$ & 1314.6 & 505.82 & $\mathrm{~ns}$ \\
\hline
\end{tabular}

$\mathrm{DH}=$ heading days, $\mathrm{DM}=$ maturity days, $\mathrm{PH}=$ plant height $(\mathrm{cm}), \mathrm{SL}=$ spike length $(\mathrm{cm}), \mathrm{KPS}=$ kernels per spike, $\mathrm{BY}=$ biomass yield $(\mathrm{kg} / \mathrm{ha}), \mathrm{GY}=$ grain yield $(\mathrm{kg} / \mathrm{ha}), \mathrm{HI}=$ harvest index, $\mathrm{L} /$ maichew $=$ Laelay-maichew, $\mathrm{T} / \mathrm{maichew}=$ Tahtay-maichew 
Table 4. Mean grain yield and agronomic traits of bread wheat varieties for at Laelay-maichew in mother trial

\begin{tabular}{|c|c|c|c|c|c|c|c|c|}
\hline \multirow[b]{2}{*}{ varieties } & \multicolumn{8}{|c|}{ Parameters } \\
\hline & $\mathrm{DH}$ & DM & $\mathrm{PH}$ & SL & KPS & $\mathrm{BY}$ & GY & $\mathrm{HI}$ \\
\hline Kakaba & $61^{b}$ & $97^{\mathrm{bc}}$ & $88.5^{b}$ & $6.7^{b}$ & 43.1 & $13000^{d}$ & $4329.5^{b}$ & $0.33^{\mathrm{b}}$ \\
\hline Mekelle-1 & $53.3^{\mathrm{d}}$ & $96^{\mathrm{bc}}$ & $83.9^{\mathrm{b}}$ & $5.8^{\mathrm{bc}}$ & 43.7 & $14000^{\mathrm{ab}}$ & $4552.7^{\mathrm{ab}}$ & $0.33^{\mathrm{b}}$ \\
\hline Mekelle-2 & $54.3^{\mathrm{cd}}$ & $96.7^{\mathrm{bc}}$ & $82.9^{\mathrm{b}}$ & $6.3^{\mathrm{b}}$ & 45.1 & $11000^{\mathrm{d}}$ & $4400^{b}$ & $0.4^{\mathrm{a}}$ \\
\hline Kingbird & $60.7^{\mathrm{b}}$ & $99^{\mathrm{b}}$ & $86.1^{\mathrm{b}}$ & $5.1^{\mathrm{cd}}$ & 44.9 & $11000^{\mathrm{d}}$ & $4561^{\mathrm{ab}}$ & $0.4^{\mathrm{a}}$ \\
\hline Hedasse & $55^{\mathrm{c}}$ & $93^{c}$ & $83.9^{\mathrm{b}}$ & $4.6^{\mathrm{d}}$ & 42.2 & $13500^{\mathrm{bc}}$ & $4013.5^{c}$ & $0.3^{\mathrm{b}}$ \\
\hline Ogolcho & $68.7^{\mathrm{a}}$ & $107^{\mathrm{a}}$ & $98.6^{\mathrm{a}}$ & $8.5^{\mathrm{a}}$ & 46.2 & $14750^{\mathrm{a}}$ & $4715.7^{\mathrm{a}}$ & $0.32^{\mathrm{b}}$ \\
\hline Mean & 58.83 & 98.2 & 87.3 & 6.2 & 44.2 & 12875 & 4429 & 0.35 \\
\hline $\mathrm{CV}(\%)$ & 1.24 & 2.2 & 4.45 & 9.8 & 6.7 & 3.9 & 3.1 & 6.6 \\
\hline $\operatorname{Lsd}(5 \%)$ & 1.32 & 3.94 & 7.07 & 1.10 & ns & 928.39 & 247.61 & 0.04 \\
\hline
\end{tabular}

Table 5. Mean grain yield and agronomic traits of bread wheat varieties at Ahforom in mother trial

\begin{tabular}{|c|c|c|c|c|c|c|c|c|}
\hline \multirow[b]{2}{*}{ varieties } & \multicolumn{8}{|c|}{ Parameters } \\
\hline & $\mathrm{DH}$ & DM & $\mathrm{PH}$ & SL & KPS & $\mathrm{BY}$ & GY & $\mathrm{HI}$ \\
\hline Kakaba & $61^{b}$ & $99^{b}$ & 89.1 & $7.8^{b}$ & 44.5 & $9666.7^{\text {cd }}$ & $3202^{b c}$ & 0.33 \\
\hline Mekelle-1 & $57^{\mathrm{c}}$ & $83^{b}$ & 85.9 & $8^{\mathrm{ab}}$ & 47.4 & $10666.7^{b}$ & $3564^{\mathrm{ab}}$ & 0.34 \\
\hline Mekelle-2 & $56.66^{\mathrm{c}}$ & $96^{\mathrm{b}}$ & 87.6 & $8^{\mathrm{ab}}$ & 48.7 & $10167^{b c}$ & $3600^{\mathrm{ab}}$ & 0.36 \\
\hline Kingbird & $61.66^{\mathrm{b}}$ & $98.7^{\mathrm{b}}$ & 87.3 & $7.5^{\mathrm{b}}$ & 47.8 & $9000^{\mathrm{d}}$ & $2947.2^{c}$ & 0.33 \\
\hline Hedasse & $54^{\mathrm{d}}$ & $95.7^{b}$ & 86.8 & $7.2^{\mathrm{b}}$ & 44.9 & $10000^{\mathrm{bc}}$ & $3558^{\mathrm{ab}}$ & 0.35 \\
\hline Ogolcho & $70.33^{a}$ & $111^{\mathrm{a}}$ & 95.3 & $8.8^{\mathrm{a}}$ & 47 & $11666.7^{\mathrm{a}}$ & $3750^{\mathrm{a}}$ & 0.32 \\
\hline Mean & 60.1 & 99.8 & 88.78 & 7.9 & 46.7 & 9889 & 3437 & 0.34 \\
\hline $\mathrm{Cv}(\%)$ & 1.65 & 2.8 & 5.3 & 6.4 & 8.98 & 5.3 & 7.9 & 9.45 \\
\hline Lsd (5\%) & 1.8 & 5.05 & ns & 0.92 & ns & 991.83 & 495.77 & ns \\
\hline
\end{tabular}

$\mathrm{DH}=$ heading days, $\mathrm{DM}=$ maturity days, $\mathrm{PH}=$ plant height $(\mathrm{cm}), \mathrm{SL}=$ spike length $(\mathrm{cm}), \mathrm{KPS}=$ kernels per spike, $\mathrm{BY}=$ biomass yield $(\mathrm{kg} / \mathrm{ha}), \mathrm{GY}=$ grain yield $(\mathrm{kg} / \mathrm{ha}), \mathrm{HI}=$ harvest index

Table 6. Combine mean of grain yield and agronomic traits of bread wheat varieties in mother trial

\begin{tabular}{|c|c|c|c|c|c|c|c|c|}
\hline \multirow[b]{2}{*}{ Varieties } & \multicolumn{8}{|c|}{ Parameters } \\
\hline & $\mathrm{DH}$ & $\mathrm{DM}$ & $\mathrm{PH}$ & $\mathrm{SL}$ & KPS & BY & GY & $\mathrm{HI}$ \\
\hline Kakaba & $60.33^{b}$ & $99.67^{b}$ & $82.87^{b}$ & $7.15^{b}$ & $40.38^{\mathrm{ab}}$ & $10222.2^{\mathrm{b}}$ & $3506.17^{\mathrm{c}}$ & 0.34 \\
\hline Mekelle-1 & $54.33^{d}$ & $98.11^{\mathrm{b}}$ & $80.22^{b}$ & $6.91^{b c}$ & $42.07^{\mathrm{ab}}$ & $11111.1^{\mathrm{ab}}$ & $3812.11^{\mathrm{ab}}$ & 0.35 \\
\hline Mekelle-2 & $55.33^{c}$ & $98 b$ & $80.4^{\mathrm{b}}$ & $7.2^{\mathrm{b}}$ & $42.58^{a}$ & $9944.4^{b c}$ & $3615.81^{b c}$ & 0.37 \\
\hline Kingbird & $60.55^{b}$ & $99.55^{b}$ & $81.07^{b}$ & $6.4^{\mathrm{cd}}$ & $42.06^{\mathrm{ab}}$ & $8777.8^{c}$ & $3112.41^{\mathrm{d}}$ & 0.36 \\
\hline Hedasse & $53.55^{d}$ & $95.55^{\mathrm{c}}$ & $79.09^{b}$ & $5.95^{\mathrm{d}}$ & $38.82^{\mathrm{b}}$ & $10111.1^{\mathrm{b}}$ & $3612.19^{b c}$ & 0.36 \\
\hline Ogolcho & $68 \mathrm{a}$ & $109.55^{\mathrm{a}}$ & $92.17^{\mathrm{a}}$ & $8.48^{a}$ & $43.73^{\mathrm{a}}$ & $11666.7^{\mathrm{a}}$ & $3950.78^{a}$ & 0.35 \\
\hline mean & 58.7 & 100.1 & 82.6 & 7.02 & 41.6 & 10306 & 3603 & 0.36 \\
\hline $\mathrm{Cv}(\%)$ & 1.6 & 2.14 & 5.4 & 8.1 & 8.4 & 12 & 8.3 & 11 \\
\hline $\operatorname{Lsd}(5 \%)$ & 0.95 & 2.11 & 4.37 & 0.56 & 3.44 & 1212.49 & 295.77 & ns \\
\hline
\end{tabular}

$\mathrm{DH}=$ heading days, $\mathrm{DM}=$ maturity days, $\mathrm{PH}=$ plant height $(\mathrm{cm}), \mathrm{SL}=$ spike length $(\mathrm{cm}), \mathrm{KPS}=$ kernels per spike, $\mathrm{BY}=$ biomass yield $(\mathrm{kg} / \mathrm{ha}), \mathrm{GY}=$ grain yield $(\mathrm{kg} / \mathrm{ha}), \mathrm{HI}=$ harvest index 


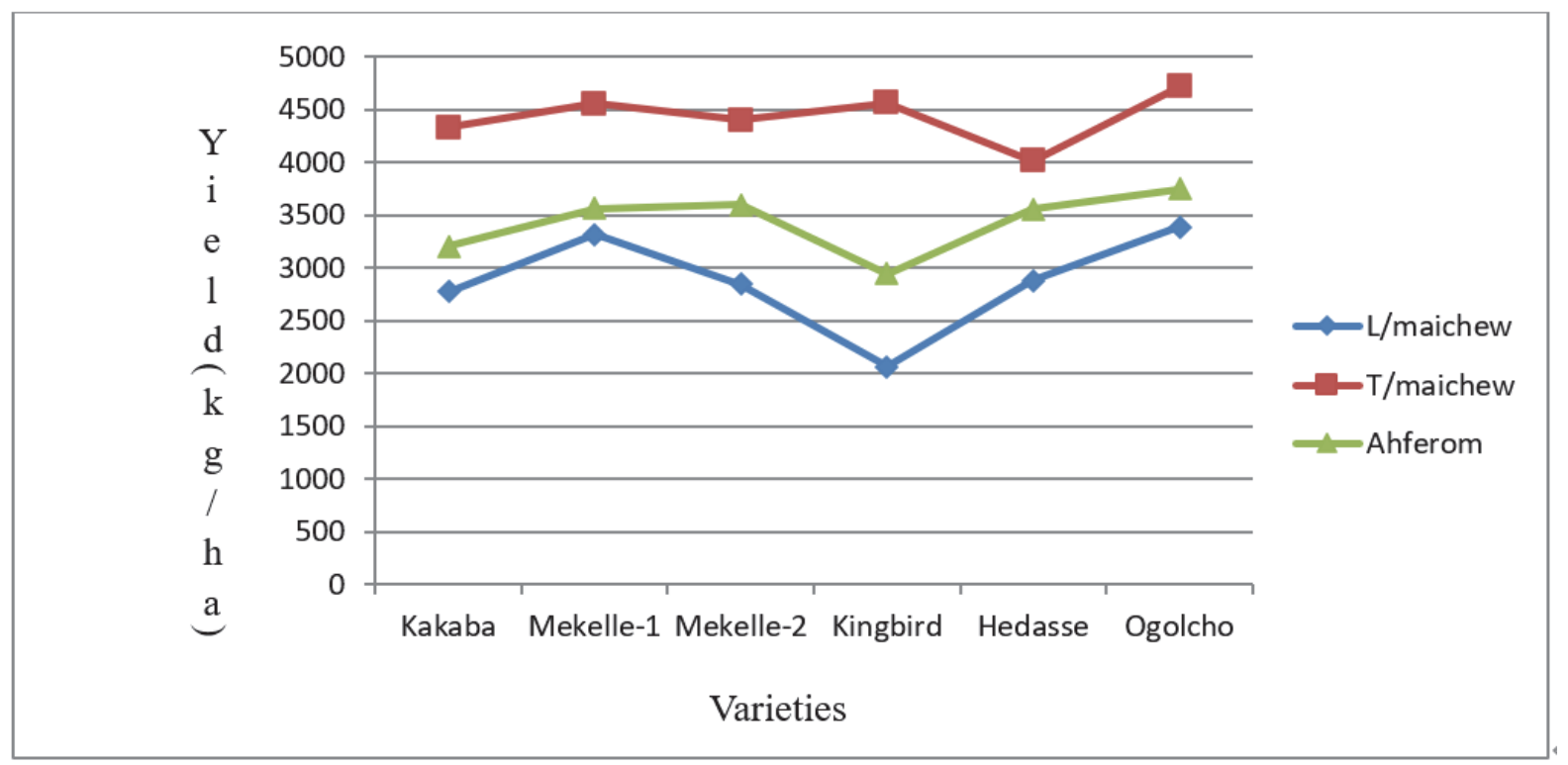

Figure 1. Mean grain yield of varieties at each location in mother trial

\subsection{Participatory Varietal Evaluation}

The evaluators ranked the bread wheat varieties at each location based on the suggested selection criteria, and ranking of the varieties for each selection criteria was done based on evaluators common score agreement. Accordingly, grain yield, disease resistance, spike length, biomass yield, plant height and seed size were identified as the most important farmers' selection criteria.

Farmers' evaluations of the varieties using direct matrix ranking are displayed on table 7, 8 and 9 at the three locations. At L/maichew testing location (Table 7) farmers varietal assessment showed that varieties; Ogolcho (4.24), Kingbird (3.8) and Kakaba (3.41) were ranked first to third, while; Hedasse was ranked lowest (2.72). Varieties with the best score indicates preferred varieties by the local community using the common criteria, therefore Ogolcho was the best, and selected by L/maichew farmers. Kingbird and kakaba were also selected by few farmers. Alebachew (2012) and Astawus (2016) were also reported similar results, where grain yield, disease resistance and spike length were identified as important farmers' criterias.

Similar to L/maichew farmers at Ahferom also preferred ogolcho over the other improved bread wheat varieties due to its better yield, good in both field and marketability preferences. Varieties; Kakaba and Mekelle-1were also selected by some farmers who has loom soil type because of their early to medium maturity. The overall ranking for the above selected top varieties showed that the high yielding varieties was also top ranked by the farmers based on both field and yield preferences ranking, this showed the positive relationship of farmers' and researchers' preferences. However, some high yielding varieties (Mekelle-2) was not selected by evaluators because their maturity was not uniform. At T/maichew variety Mekelle-1 was preferred by the farmers followed by Kakaba and kingbird, this is because mekelle-1 is very early maturing variety which require clay loam soil type with lower altitude. Therefore location specific varietal selection is important since it affects the qualitative and quantitative traits of the varieties and varieties should be grown at climatic conditions that suited their growth for good seed or grain production. 
Table 7. Farmers' preference score and direct matrix ranking of bread wheat varieties on baby trial at Laelaymaichew district

\begin{tabular}{lllllllll} 
& \multicolumn{3}{l}{ Parameters and scores } & \multicolumn{7}{c}{} \\
\cline { 2 - 8 } Varieties & GY & $\begin{array}{l}\text { Disease } \\
\text { Resistance }\end{array}$ & SL & DM & PH & BY & Mean & Rank \\
\hline Ogolcho & 4.37 & 3.23 & 4.8 & 3.2 & 4.81 & 5 & 4.24 & 1 \\
Mekele-1 & 3.73 & 3 & 3.64 & 3.3 & 3.69 & 2.7 & 3.34 & 4 \\
Kakaba & 3.47 & 3 & 3.63 & 3.9 & 3.51 & 3 & 3.41 & 3 \\
Hedasse & 3 & 2 & 3 & 3 & 3 & 2.32 & 2.72 & 6 \\
Mekele-2 & 3 & 3 & 3.25 & 3.7 & 3 & 2.51 & 3.07 & 5 \\
Kingbird & 3 & 4 & 5 & 3 & 4 & 2.9 & 3.80 & 2 \\
\hline
\end{tabular}

$\mathrm{DM}=$ maturity days, $\mathrm{PH}=$ plant height $(\mathrm{cm}), \mathrm{SL}=$ spike length $(\mathrm{cm}), \mathrm{BY}=$ biomass yield $(\mathrm{kg} / \mathrm{ha}), \mathrm{GY}=$ grain yield $(\mathrm{kg} / \mathrm{ha})$, Disease resistance

Table 8. Farmers' preference score and direct matrix ranking of bread wheat varieties on baby trial at Tahtaymaichew district

\begin{tabular}{lllllllll}
\cline { 2 - 9 } & \multicolumn{1}{c}{ Parameters and scores } & & & & & & \\
\cline { 2 - 9 } Varieties & GY & Disease Resistance & SL & DM & PH & BY & mean & Rank \\
\hline Ogolcho & 3.69 & 3 & 3.72 & 2.6 & 4 & 3.58 & 3.43 & 4 \\
Mekele-1 & 5 & 4 & 4 & 4.7 & 4 & 4 & 4.28 & 1 \\
Kakaba & 3.56 & 4 & 3.58 & 2.5 & 4.44 & 3.64 & 3.62 & 2 \\
Hedasse & 2.57 & 2 & 2.47 & 3 & 2.5 & 2.62 & 2.53 & 6 \\
Mekele-2 & 3.31 & 2.39 & 2 & 3.3 & 3 & 2.35 & 2.73 & 5 \\
Kingbird & 4 & 2.33 & 3 & 3.4 & 4.3 & 4 & 3.51 & 3 \\
\hline
\end{tabular}

$\mathrm{DM}=$ maturity days, $\mathrm{PH}=$ plant height $(\mathrm{cm}), \mathrm{SL}=$ spike length $(\mathrm{cm}), \mathrm{BY}=$ biomass yield $(\mathrm{kg} / \mathrm{ha}), \mathrm{GY}=$ grain yield $(\mathrm{kg} / \mathrm{ha})$, Disease resistance

Table 9. Farmers' preference score and direct matrix ranking of bread wheat varieties on baby trial at Ahferom district

\begin{tabular}{lllllllll}
\hline & \multicolumn{7}{c}{ Parameters and scores } \\
\cline { 2 - 9 } Varieties & GY & $\begin{array}{l}\text { Disease } \\
\text { Resistance }\end{array}$ & SL & DM & PH & BY & mean & Rank \\
\hline Ogolcho & 4.05 & 3.56 & 5 & 3.1 & 5 & 5 & 4.29 & 1 \\
Mekelle-1 & 3.78 & 2.91 & 3.78 & 4 & 4 & 4 & 3.75 & 3 \\
Kakaba & 3.78 & 3.8 & 3.36 & 4.6 & 3.73 & 3.64 & 3.82 & 2 \\
Hedasse & 3.57 & 2 & 2 & 2.4 & 2.67 & 2 & 2.44 & 6 \\
Mekelle-2 & 4 & 2.14 & 3.67 & 4.7 & 3 & 2 & 3.25 & 5 \\
Kingbird & 3 & 4.33 & 3 & 3.4 & 4 & 4 & 3.62 & 4 \\
\hline
\end{tabular}

$\mathrm{DM}=$ maturity days, $\mathrm{PH}=$ plant height $(\mathrm{cm}), \mathrm{SL}=$ spike length $(\mathrm{cm}), \mathrm{BY}=$ biomass yield $(\mathrm{kg} / \mathrm{ha}), \mathrm{GY}=$ grain yield $(\mathrm{kg} / \mathrm{ha})$, Disease resistance 


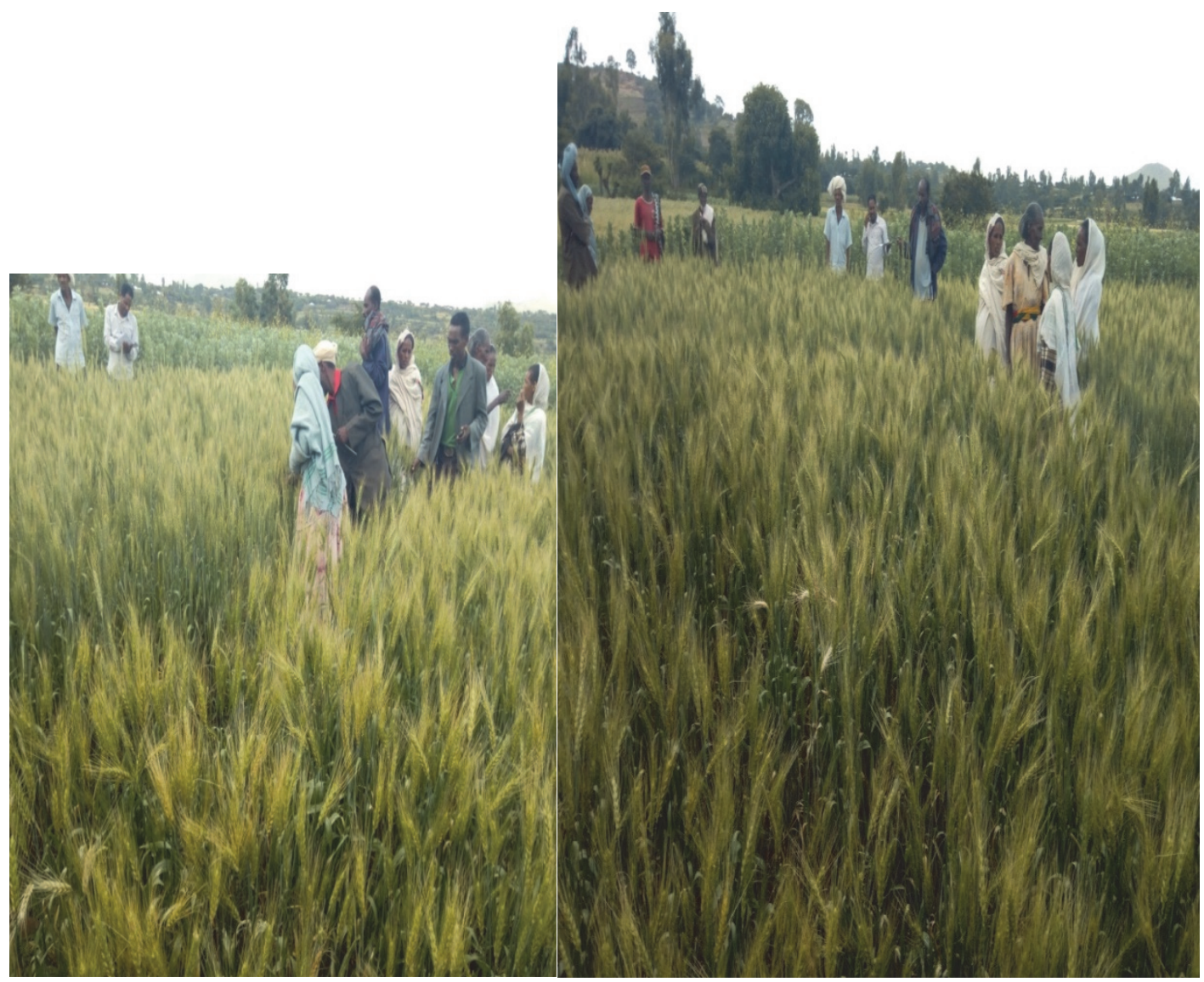

Figure 2. Participatory variety selection

\section{Conclusion and Recommendation}

Six varieties; Kakaba (most popular in the tested locations) as standard check, Mekelle-1, Mekelle-2, Ogolcho, Kingbird and Hedasse were evaluated with the objective of selecting adaptable and best performing bread wheat varieties with full participation of farmers. Traits like grain yield, spike length, biomass yield, days to maturity and seed size were selected by the farmers based on the criteria they set. Accordingly varieties Ogolcho (first) and Kakaba (second) were selected both at L/maichew (having verti soil with good rain fall distribution) and Ahferom (high altitude area) districts because Ogolcho is medium maturing variety and required good rainfall distribution. At T/maichew Mekelle-1 was selected by the farmers which was early matured and high yielder variety. Therefore, for cost effective and fast track delivery of new and existed technologies to farmers future breeding program should include the participation of farmers and their selection preferences early during varietal development program.

\section{References}

Alebachew, H. (2012). Participatory and performance evaluation of improved bread wheat (Triticum aestivum L.) varieties in degua Tibien and ofla woredas of tigray region, Ethiopia M.Sc. Thesis, Haramaya University, Haramaya, Ethiopia.

Astawus, E. (2016). Participatory and Performance Evaluation Of Improved Bread Wheat (Triticum Aestivum L.) Varieties In Two Districts Of Arsi Zone, Ethiopia. MSc Thesis Haramaya University, School of Graduate studies Haramaya Ethiopia.

Ayalew, S. (2017). Participatory Demonstration and Evaluation of Improved Variety of Tef in Selected Districts of West and Kellem Wollega Zones. International Journal of Education, Culture and Society, 2, 143-146.

Bellon, M. R., \& Reeves, J. (2002). Quantitative Analysis of Data from Participatory Methods in Plant Breeding. Agricultural Economics., 103, 233-244.

Boef, W. S., \& Thijssen, M. H. (2006). Participatory tools working with crops, varieties and seeds. A guide for professionals applying participatory approaches in agro biodiversity management, plant breeding and seed sector development Wageningen, Wageningen International. pp. 29. 
Ceccarelli, S. (2012). Plant breeding with farmers - a technical manual. ICARDA.

Fano, D., \& Tadeos, Sh. (2017). Participatory Varietal Selection of Bread Wheat Cultivars (Triticum Aestivum L.) for Moisture Stress Environment of Somali Regional State of Ethiopia. Journal of Biology, Agriculture and Healthcare, 7, 61-63.

FAOStat (Food and Agricultural Organization Statistics). 2015. Agricultural production statistics. (http://www.fao.org/faostat) Accessed on 08 November 2016).

Joshi, K. D., Sthapit. B. R., Subedi, M., \& Witcombe, J. R. (2002). Enhancing on-farm varietal diversity through participatory varietal selection: a case study of Chaite Rice in Nepal. Expl Agric., 33, 335-344.

Kifle, Z., Birhanu, T., \& Mekonen, G. (2018). Farmers Participatory Evaluations and Selection of Bread Wheat (Triticum aestivum.L) Varieties in Cheha District, Gurage Zone, Ethiopia. International Journal of Scientific and Research Publications, 8, 783-788. http://dx.doi.org/10.29322/IJSRP.8.12.2018.p8497

Singh, Y. P., Nayak, A. K., Sharma, D. K., Gautam, R. K., Singh, R. K., Ranbir, S., ... Ismail, A. M. (2014). Farmers" Participatory Varietal Selection: A Sustainable Crop Improvement Approach for the 21st Century. Agroecology and Sustainable Food Systems, 38(4), 427-444.

Sperling, L. E., Ashby, J. A., Smith, M. E., Weltzen, E., \& McGuire, S. (2001). Participatory plant breeding approaches and results. Euphytica, 122, 439-450

White, J. W., Tanner, D. G., \& Corbett J. D. (2001). An Agro-Climatological Characterization of Bread Wheat Production Areas in Ethiopia. NRG-GIS Series 01. Mexico, D.F.: CIMMYT.

Witcombe, J. R, Joshi, A., Joshi, K. D., \& Sthapit, B. R. (1996). Farmers participatory crop improvement. I. varietal selection and breeding methods and their impacts on biodiversity. Expl Agric, 32, 445-460.

Workineh, A., Berhanu, A., \& Demelash, K. (2014). Participatory Evaluation and Selection of Bread Wheat (Triticum aestivum L.) Varieties: Implication for Sustainable Community Based Seed Production and Farmer Level Varietal Portfolio Managements at Southern Ethiopia. World Journal of Agricultural Research, 2(6), 315-320.

\section{Copyrights}

Copyright for this article is retained by the author(s), with first publication rights granted to the journal.

This is an open-access article distributed under the terms and conditions of the Creative Commons Attribution license (http://creativecommons.org/licenses/by/4.0/). 